\title{
GLASS BEAD TRANSFORMATION METHOD FOR GRAM-POSITIVE BACTERIA
}

\author{
Pongsak Rattanachaikunsopon", Parichat Phumkhachorn
}

Department of Biological Science, Ubon Ratchathani University, Warin Chamrap, Ubon Ratchathani 34190, Thailand

Submitted: February 10, 2009; Returned to authors for corrections: April 26, 2009; Approved: May 15, 2009.

\begin{abstract}
A simple, inexpensive and reproducible transformation method was developed for Gram-positive bacteria.

It was based on agitation of bacterial protoplasts with glass beads in the presence of DNA and polyethylene glycol. By using this method, introduction of pGK12 into protoplasts of several strains of Gram-positive bacteria was achieved.
\end{abstract}

Key words: transformation; Gram-positive bacteria; glass bead

\section{INTRODUCTION}

The difficulty in introducing DNA into cells of Grampositive bacteria is one of the major factors that hinders genetic studies of Gram-positive bacteria. The thick peptidoglycan layer in their cell walls is considered a potential barrier to DNA uptake. Transformation of these organisms cannot occur naturally but can be accomplished by particular transformation methods such as protoplast transformation and electroporation. Protoplast transformation was developed for enzymatic removal of the cell wall to create protoplasts. In the presence of polyethylene glycol, DNA uptake by protoplasts is facilitated. It was developed for some Gram-positive bacteria $(5,6,10,12,14,17)$. Because of its low and highly variable efficiency and time consuming protocol, this method is rarely used. Presently, electroporation is the most commonly used transformation method for Gram-positive bacteria. It involves the application of high voltage electric pulse of short duration to induce the formation of transient pores in cell walls and membranes. Under appropriate conditions, DNA present in surrounding environment may enter through the pores. This method was successfully used to introduce DNA into several strains of Gram-positive bacteria $(1-4,7-9,11,15,16)$. Although electroporation can be used to transform the bacteria with high efficiency, it cannot be performed by small and less-equipped laboratories because of the requirement of expensive and specialized equipment. In this study, glass bead transformation was proposed as a simple, inexpensive and reproducible transformation method for Gram-positive bacteria.

Glass bead transformation was performed by using of Gram-positive bacteria as recipients for pGK12, a $4.4 \mathrm{~kb} E$. coli/Lactococcus shuttle vector carrying an erythromycin resistance gene. The bacteria used in transformation experiments were Enterococcus faecalis TISTR 927, Lactobacillus casei ATCC 393, Lactococcus lactis DSM 20481, Leuconostoc dextranicum ATCC 19255, Listeria innocua DSM 20649, Staphylococcus aureus ATCC 25923 and Streptococcus pneumoniae ATCC 10015. 
To obtain protoplasts of Gram-positive bacteria, cultures of the bacteria were grown at $37^{\circ} \mathrm{C}$ in $30 \mathrm{ml}$ of $\mathrm{BHI}$ broth to mid log phase. Cells were harvested by centrifugation at $5,000 \mathrm{xg}$ for $5 \mathrm{~min}$, washed in distilled water, and suspended in $5.0 \mathrm{ml}$ of $0.5 \mathrm{M}$ sorbitol in $0.01 \mathrm{M}$ Tris-hydrochloride $(\mathrm{pH}$ 7.0). The cell suspension was mixed with mutanolysin (at the final concentration of $50 \mu \mathrm{g} / \mathrm{ml}$ ) and then incubated at $37^{\circ} \mathrm{C}$ for $30 \mathrm{~min}$. Protoplasts were pelleted at 5,000 xg for $5 \mathrm{~min}$, washed in $10 \mathrm{ml}$ of transformation buffer $(0.5 \mathrm{M}$ sorbitol, $0.02 \mathrm{M}$ maleate, $0.02 \mathrm{M} \mathrm{MgCl}_{2}$, pH 6.5), and resuspended in $1 \mathrm{ml}$ of transformation buffer.

Glass bead transformation of Gram positive bacteria was conducted as follows. Aliquots of $0.5 \mathrm{ml}$ of protoplast suspension were placed in $15 \mathrm{ml}$ conical disposable polypropylene centrifuge tubes (Corning, USA). One $\mu \mathrm{g}$ of pGK12 was added to the protoplasts, followed immediately by the addition of $500 \mu \mathrm{l}$ of $30 \%$ polyethylene glycol 6,000 (PEG 6,000) and $0.3 \mathrm{~g}$ of acid washed glass beads (212-300 $\mu \mathrm{m}$ in diameter, Sigma, USA). Protoplasts were agitated at the highest speed on a vortex mixer for $15 \mathrm{sec}$, and then diluted by the addition of $10 \mathrm{ml}$ of transformation buffer. After the beads were allowed to settle, agitated protoplast suspension was transferred to a new $15 \mathrm{ml}$ conical tube. Cells were pelleted by centrifugation at 5,000 $\mathrm{xg}$ for $5 \mathrm{~min}$ and suspended in $1 \mathrm{ml}$ of BHI supplemented with $0.5 \mathrm{M}$ sorbitol. After incubation at $37^{\circ} \mathrm{C}$ for $1 \mathrm{~h}$, transformants were recovered by plating the protoplast culture onto BHI agar containing $0.5 \mathrm{M}$ sorbitol and erythromycin at the final concentration of $3 \mu \mathrm{g} / \mathrm{ml}$ and incubated at $37^{\circ} \mathrm{C}$ for 5 to 7 days. Transformation frequency was expressed as erythromycin resistant colonies per $1 \mu \mathrm{g}$ of $\mathrm{pGK} 12$, and values reported represented the mean from 5 separate experiments. Transformation frequencies and numbers of transformants obtained from these experiments are shown in Table 1. The presence of pGK12 in transformants was confirmed by Southern hybridization analysis using DIGlabeled pGK12 as a probe. These results suggest that glass bead transformation can be used as transformation method for Gram-positive bacteria with acceptable efficiency and high reproducibility.

Table 1. Numbers of transformants and transformation frequencies obtained from glass bead transformation of Gram-positive bacteria with pGK12

\begin{tabular}{|c|c|c|}
\hline $\begin{array}{c}\text { Gram-positive } \\
\text { bacteria }\end{array}$ & $\begin{array}{c}\text { Number of } \\
\text { transformanats } \\
\left(\times \mathbf{1 0}^{\mathbf{3}}\right)^{\mathbf{a}} \\
\end{array}$ & $\begin{array}{c}\text { Transformation } \\
\text { frequency } \\
\text { (per } \mu \mathrm{g} \text { of pGK12) }\end{array}$ \\
\hline E. faecalis & $3.8,5.0,4.4,4.6,5.2$ & $4.60 \times 10^{3}$ \\
\hline L. casei & $4.3,4.0,4.8,5.0,4.6$ & $4.54 \times 10^{3}$ \\
\hline L. lactis & $6.9,6.3,7.1,6.7,6.1$ & $6.62 \times 10^{3}$ \\
\hline L. dextranicum & $5.8,6.1,4.8,5.7,5.0$ & $5.48 \times 10^{3}$ \\
\hline L. innосиа & $5.1,4.7,4.5,5.3,4.0$ & $4.72 \times 10^{3}$ \\
\hline S. aureus & $3.3,3.8,4.2,3.0,3.5$ & $3.56 \times 10^{3}$ \\
\hline S. pneumoniae & $3.6,4.8,4.3,3.2,4.5$ & $4.08 \times 10^{3}$ \\
\hline
\end{tabular}

a obtained from 5 separate experiments

Some parameters were tested for their effects on transformation including amount of plasmid DNA, concentration and molecular weight of PEG and agitation time. Since L. lactis gave the highest transformation frequency in glass bead transformation, it was used as a recipient for pGK12 in the following experiments.

Quantities of pGK12 DNA ranging from 0.5 to $5.0 \mu \mathrm{g}$ were used in glass bead transformation of L. lactis. Results indicated that transformation frequencies were somewhat stable at the highest level when DNA between 1.0 and $3.0 \mu \mathrm{g}$ was used. Interestingly, increase of the amount of pGK12 above $3.0 \mu \mathrm{g}$ caused higher numbers of transformants recovered but lower numbers of transformation frequency (Fig. 1). It is not known if this is due to an inappropriate proportion of amount of protoplasts to amount of DNA used in the transformation. Similar result was found in protoplast transformation of Enterococcus faecalis OG1RF with pGB354. It was reported that increase of plasmid concentration beyond $0.5 \mu \mathrm{g}$ per $\mathrm{ml}$ of transformation mixture caused reduction of transformation frequency (17). 


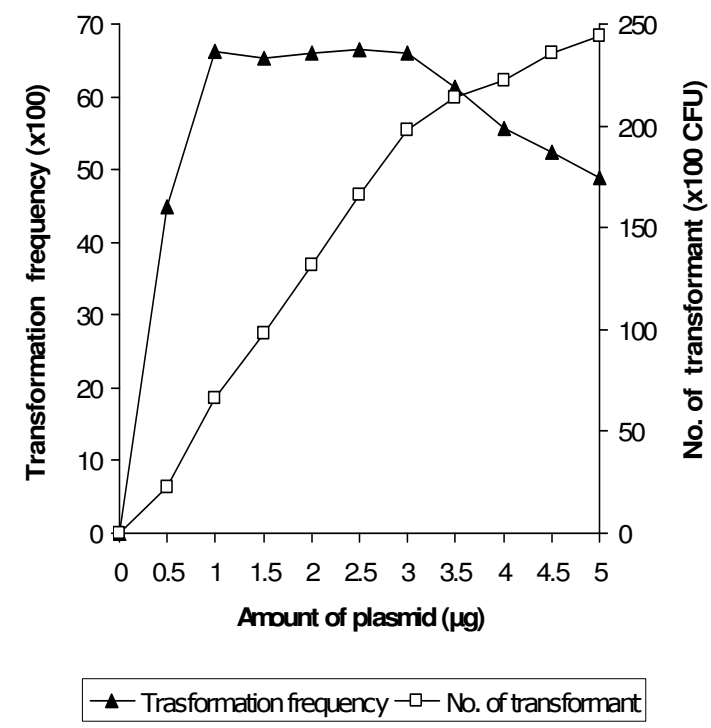

Figure 1. Transformation frequencies and numbers of transformants obtained from glass bead transformation of $L$. lactis with different amounts of pGK12.

Glass bead transformation of L. lacis were designed to use PEG with 3 different molecular weights $(3,350,6,000$ and 8,000$)$ at various concentrations including $0 \%, 5 \%, 10 \%$, $15 \%, 20 \%, 25 \%$ and $30 \%$. Molecular weight of PEG was shown not to have any effect on transformation. However, transformation frequency was found to be affected by concentration of PEG. The highest transformation frequency was observed in the transformation using 10\% PEG. The optimal concentrations of PEG for protoplast transformation of Streptomyces spp., Streptococcus lactis, Bacillus subtilis and Enterococcus faecalis OG1X were reported to be $20 \%$ (2), $22.5 \%$ (6), $30 \%$ (2) and 40\% (17), respectively. Agitation protoplasts with glass beads may be the reason for the reduction of concentration of PEG used in glass bead transformation.

Effect of agitation time on transformation was evaluated. Protoplasts of $L$. lacis subjected to glass bead transformation were agitated with glass beads for different periods of time ranging from 0 to $30 \mathrm{sec}$. Transformation was most efficient between 10 and $15 \mathrm{sec}$ of agitation. No transformants was recovered in the glass bead transformation without agitation or with agitation for $30 \mathrm{sec}$ (Fig. 2). Protoplasts of L. lactis were also mixed with $15 \%$ PEG and $1 \mu \mathrm{g}$ of pGK12 without any agitation for 10, 20, 30, 40, 50 and $60 \mathrm{~min}$. No transformant was observed in every mixing time. The results suggest that the transformation cannot occur naturally and the agitation of protoplasts with glass beads may be necessary for the process to occur.

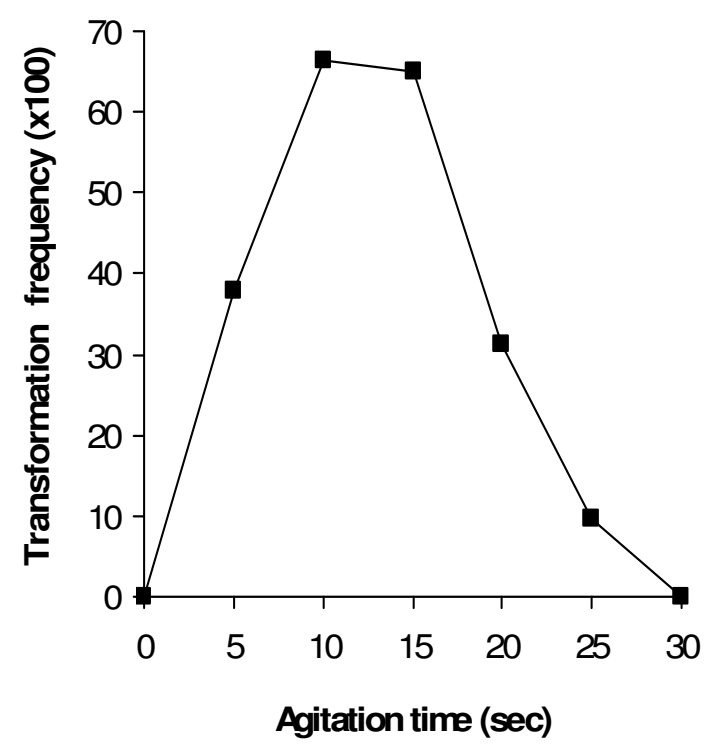

Figure 2. Transformation frequencies obtained from glass bead transformation of L. lactis with pGK12 using different agitation times.

In sum, we would like to stress that this is the first report of the transformation of Gram-positive bacteria using glass bead. Because of its convenience, cost saving, high reproducibility and acceptable efficiency, it may be an alternative method for transformation of Gram-positive bacteria with plasmid DNA.

\section{ACKNOWLEDGEMENTS}

We are grateful to Dr. Jan Kok, University of Groningen, the Netherlands for providing pGK12. 


\section{REFERENCES}

1. Aukrust, T.W.; Brurberg, M.B.; Nes, I.F.N. (1995). Transformation of Lactobacillus by electroporation. Methods Mol. Biol., 47, 201-208.

2. Dunny, G.M.; Lee, L.N.; LeBlanc, D.J. (1991). Improved electroporation and cloning vector system for Gram-positive bacteria. Appl. Environ. Microbiol., 57, 1194-1201.

3. Friesenegger, A.; Fiedler, S.; Devriese, L.A.; Wirth, R. (1991). Genetic transformation of various species of Enterococcus by electroporation. FEMS Microbiol. Lett., 79, 323-327.

4. Holo, H.; Nes, I.F. (1989). High-frequency transformation, by electroporation of Lactococcus lactis subsp. cremoris grown with glycine in osmotically stabilized media. Appl. Environ. Microbiol., 55, 3119-3123.

5. Hopwood, D.A. (1981). Genetic studies with bacterial protoplasts. Annu. Rev. Microbiol., 35, 237-272.

6. Kondo, J.K.; McKay, L.L. (1984). Plasmid transformation of Streptococcus lactis protoplasts: optimization and use in Molecular Cloning. Appl. Environ. Microbiol., 48, 252-259.

7. Leathers, T.D.; Jones, J.D.; Wyckoff, H.A. (2004). Transformation of alternan-producing strains of Leuconostoc electroporation. Biotechnol. Lett., 26, 1119-1124.

8. Lofblom, J.; Kronqvist, N.; Uhlen, M.; Stahl, S. (2007). Optimization of electroporation-mediated transformation: Staphylococcus carnosus as model organism. J. Appl. Microbiol., 102, 736-747.

9. Luchansky, J.B.; Muriana, P.M.; Klaenhammer, T.R. (1988). Application of electroporation for transfer of plasmid DNA to Lactobacillus, Leuconostoc, Listeria, Pediococcus, Bacillus,
Staphylococcus, Enterococcus and Propionibacterium. Mol. Microbiol., 2, 637-646.

10. Marekova, M.; Kmet, V.; Javorsky P. (1996). Transformation of Streptococcus bovis protoplasts by plasmid DNA. Lett. Appl. Microbiol., 22, 159-161.

11. Mason, C.K.; Collins, M.A.; Thompson, K. (2005). Modified electroporation protocol for lactobacilli isolated from the chicken crop facilitates transformation and the use of genetic tool. J. Microbiol. Methods, 60, 353-363.

12. Morelli, L.; Cocconcelli, P.S.; Bottazzi, V.; Damiani, G.; Ferreti, L.; Sgaramella, V. (1987). Lactobacillus protoplast transformation. Plasmid, 17, 73-75.

13. Romero, D.; Pérez-García, A.; Veening, J.W.; de Vicente, A.; Kuipers, O.P. (2006). Transformation of undomesticated strains of Bacillus subtilis by protoplast electroporation. J. Microbiol. Methods, 66, 556559.

14. Simon, D.; Rouault, A.; Chopin, M.C. (1986). High-efficiency transformation of Streptococcus lactis protoplasts by plasmid DNA. Appl. Environ. Microbiol., 52, 394-395.

15. Teresa Alegre, M.; Carmen Rodriguez, M.; Mesas, J.M. (2004). Transformation of Latobacillus plantarum by electroporation with in vitro modified plasmid DNA. FEMS Microbiol. Lett., 241, 73-77.

16. Turgeon, N.; Laflamme, C.; Ho, J.; Duchaine, C. (2006). Elaboration of an electroporation protocol for Bacillus cereus ATCC 14579. J. Microbiol. Methods, 67, 543-548.

17. Wirth, R.; An, F.Y.; Clewell, D.B. (1986). Highly efficient protoplast transformation system for Streptococcus faecalis and a new Escherichia coli-S. faecalis shuttle vector. J. Bacteriol., 165, 831-836. 